\title{
Effect of natural and chemical insecticides on Hyalopterus pruni and Armeniaca vulgaris
}

\author{
${\text { Akram } \mathrm{Ali}^{1 \star} \text { and Saleh Al-Quraishy }}^{2}$ \\ ${ }^{1}$ Botany and Microbiology Department, College of Science, King Saud University, Riyadh 11451, PO Box: 2455, \\ Kingdom of Saudi Arabia. \\ ${ }^{2}$ Zoology Department, College of Science, King Saud University., Riyadh 11451, PO Box: 2455, Kingdom of Saudi \\ Arabia. \\ Accepted 14 April, 2008

\begin{abstract}
Experiments were carried out to evaluate the effect of water extracts of Fagonia arabica, Salix alba and Anthmis pseudocotula and their mixtures with chemical insecticide (Malathion) on growth of Hyalopterus pruni and characters of Armeniaca vulgaris plants and their soils. The data revealed that $F$. arabica extract at $20 \%$ concentration was the most effective followed by S. alba which recorded 62.66 and $56.16 \%$ reduction in $H$. pruni population density, respectively. While the mixture of Malathion with $F$. arabica or S. alba or A. pseudocotula extracts (each one at half concentration) results in $57.88,57.42$ and $60.86 \%$ reduction in aphid population, respectively. The plant extracts treatment resulted in significant increase in chlorophyll pigments and total carbohydrates in $A$. vulgaris whereas carotenoids and total protein content decreased (except $S$. alba extract treatment which increased total protein content). Soil cations; $\mathrm{Ca}^{++}, \mathrm{Na}^{+}, \mathrm{Mg}^{++}, \mathrm{K}^{+}$and anions; $\mathrm{SO}_{4}{ }^{2-}, \mathrm{HCO}_{3}{ }^{-}, \mathrm{Cl}^{-}$increased with all plant extracts treatment with exception of $A$. pseudocotula extract treatment that decreased $\mathrm{HCO}_{3}{ }^{-}$concentrations. This study recommended that natural insecticides were more effective and safe than chemical ones in pest control.
\end{abstract}

Key words: Natural insecticides, chemical insecticides, treatments, side-effect, ecosystem.

\section{INTRODUCTION}

Fruits are considered strategic crops and have obtained special attention all over the world. Aphids are considered the main pests which threaten the quantity and quality of the yield of these crops. The recent widespread application of pesticides for controlling the pests has a serious effect on the natural balance of the ecosystem. Several investigators in different parts of the world have initiated large-scale screening efforts to find plants which have interesting physiological effects on pests (Ghamry 1986, Venkaietan et al., 1987 and Bandara et al., 1990). Previous studies have not recorded the use of natural extracts of Fagonia arabica, Salix alba and Anthmis pseudocotula and their mixtures with chemical insecticide (Malathion).

*Corresponding author. E-mail: akram692000@yahoo.com.Tel: 00966557554020 . Fax: 0096614675833.
Therefore our investigations were carried out to evaluate these plant extracts to minimize the growth of Hyalopterus pruni populations on apricot trees (Armeniaca vulgaris) and their effects on the tree and their supporting soils.

\section{MATERIALS AND METHODS}

Preparation of extracts

The plants $F$. arabica, S. alba and $A$. pseudocotula were immersed in warm water for $48 \mathrm{~h}$ and filtered to get the plant extract for each plant.

\section{Preparation of concentrations}

Crude solution of plant extracts used at rate of $750 \mathrm{ml}$ from each plant extract was diluted with 3 liter water to reach $20 \%$ final concentration. The recommended concentration of Malathion (57\% $\mathrm{EC}$ ) is $250 \mathrm{ml} / 100$ liter water. Each plant extract-Malathion mixture was prepared by using the half of the preceding rates. 


\section{Application against $\boldsymbol{H}$. pruni on apricot trees}

To study the initial and residual toxicity of the tested plant extracts against $H$. pruni individuals, the experimental area with 24 apricot trees, were divided into 8 treatments; each one included three trees (3 replicates for each treatment). Spraying was carried out by using a knapsack motor sprayer. Samples from each treatment were collected randomly by taking 20 leaf/tree from three canopy positions (upper, middle, lower) of the tree in plastic bags just before the insecticidal application. This include pretreatment samples and treatment collection after 2, 3, 5, 7, and 9 days post treatment. The samples were examined directly by the aid of stereoscope microscope in the laboratory, where the individuals of $H$ pruni were counted pre- and post-treatment. The reduction percentages of aphid population were calculated according to Handerson and Tilton (1955) formula.

\section{Soil analysis}

The soil profiles supporting apricot trees were sampled and collected in plastic bags for chemical analysis. The soil samples were taken at depth $20 \mathrm{~cm}$ after one week of application; the samples were air dried, sieved through $2 \mathrm{~mm}$ meshes and analysis was carried out. Seven hundreds $\mathrm{ml}$ of distilled water were added to $140 \mathrm{~g}$ of air-dried soil and were shaken for two hours. The heavier particles were allowed to settle and the supernatant liquid was decanted into Pastur Chamber land filter. After repeated filtration, clear soil solution was obtained then determination of anions and cations were carried out according to Jackson (1967).

\section{Pigment analysis}

The photosynthetic pigments (chlorophyll a, chlorophyll b and carotenoids) were determined spectrophotometrically according to Metzner et al. (1965). A known fresh weight of leaves was homogenized in $85 \%$ aqueous acetone for $5 \mathrm{~min}$. The homogenate was centrifuged and the supernatant was made up to known volume with $85 \%$ acetone and measured against a blank of pure $85 \%$ aqueous acetone at 3 wavelengths of $452.5,644$ and $663 \mathrm{~nm}$. Taking into consideration the dilution made, it was possible to determine the concentrations of the pigment fractions (chlorophyll a, chlorophyll $\mathrm{b}$ and carotenoids) as $\mu \mathrm{g} / \mathrm{ml}$ using the following equations:

Chlorophyll $\mathrm{a}=10.3$ E $663-0.918$ E 644

Chlorophyll b $=19.7$ E $644-3.87$ E 663

Carotenoids $=4.2$ E $425.5-(0.0264$ chlorophyll $\mathrm{a}+0.426$ chlorophyll b).

\section{Estimation of carbohydrates}

Dry sample $(0.05 \mathrm{~g})$ was hydrolyzed with $20 \mathrm{ml} \mathrm{HCl}(6 \mathrm{~N})$ in carbohydrates tube for $6 \mathrm{~h}$ in boiling water bath and then filtrated using whatman $1.20 \mathrm{ml} \mathrm{NaOH}(6 \mathrm{~N})$ was added to the filtrate and made up to $100 \mathrm{ml}$ with distilled water. Five $\mathrm{ml}$ from the filtrate was taken in test tube and $2 \mathrm{ml}$ of 3,5 dinitrosalicylic acid was added. The mixture was shaken and heated for 10 min in boiling water bath, and immediately cooled in ice. The optical density was measured at $550 \mathrm{~nm}$ using spectrophotometer. The concentrations were obtained from standard curve $(\mathrm{mg} / \mathrm{g})$.

\section{Estimation of protein}

Nitrogen percentage was measured by taking $0.2 \mathrm{ml}$ from the digested sample in $25 \mathrm{ml}$ flask, then distilled water was added to reach half of the flask. $1 \mathrm{ml}$ of Nesler's solution was then added. Reading was made at $420 \mathrm{~nm}$ using. Then total protein percentage determined according to the following equation:

Protein $(\%)=\mathrm{N}(\%) \times 6.25$

\section{Statistical analysis}

The data obtained were subjected to statistical analysis by ANOVA using SPSS version 11. Duncan's multiple range tests was used to determine the significant of the difference between mean values of the treatments.

\section{RESULTS AND DISCUSSION}

\section{Effect of extracts on $H$. pruni}

Data in Table 1 summarized the efficiency of the plant extracts and its mixtures with Malathion as well as Malathion alone against $H$. pruni populations. Initial reduction percentages of aphid population measured after $48 \mathrm{~h}$ post treatment ranged between a minimum of $27.82 \%$ for A. pseudocotula extract to a maximum of $39.71 \%$ for S. alba extract comparing with Malathion which recorded $71.82 \%$ as initial effect. The residual reduction percentages mean of aphids measured at days (3, 5, 7 and 9 post treatment) ranged between a minimum of $52.48 \%$ for $A$. pseudocotula extract to a maximum of $62.66 \%$ for $F$. arabica extract comparing with Malathion that recorded $71.78 \%$. These results were in agreement with Ghamry (1986) who tested the efficacy of five plant extracts against aphids on citrus trees, Venkaietan et al. (1987) when investigating various plant extracts on Aphis gossypii (Glov.) populations and Hala (2000) who reported that aqueous extracts of some plants causing high reduction percentages of aphids population.

\section{Cations content}

Results remarked in Table 2 showed that $\mathrm{Ca}^{++}, \mathrm{Na}^{+}, \mathrm{Mg}^{++}$ and $\mathrm{K}^{+}$have the highest concentrations in the soil supporting treated apricot trees with $S$. alba extract. Values of $\mathrm{Ca}^{++}$concentrations in the soil ranged between 197.97 and $676.7 \mathrm{mg} / \mathrm{L}, \mathrm{Na}^{+}$between 170 and $280 \mathrm{mg} / \mathrm{L}$, $\mathrm{Mg}^{++}$between 63.81 and $165.68 \mathrm{mg} / \mathrm{L}$ and $\mathrm{K}^{+}$between 16 and $44 \mathrm{mg} / \mathrm{L}$. The control values were $141.41,125,36.81$ and $14 \mathrm{mg} / \mathrm{L}$ for $\mathrm{Ca}^{++}, \mathrm{Na}^{+}, \mathrm{Mg}^{++}$and $\mathrm{K}^{+}$, respectively.

\section{Anions content}

Data listed in Table 3 showed that bicarbonates $\left(\mathrm{HCO}_{3}{ }^{-}\right)$, sulphates $\left(\mathrm{SO}_{4}{ }^{2-}\right)$ and chlorides $\left(\mathrm{Cl}^{-}\right)$contents have the 
Table 1. Effect of plant extracts and malathion and their mixtures on the number of Hyalopterus pruni under field conditions.

\begin{tabular}{|c|c|c|c|c|c|c|c|c|c|c|c|c|c|}
\hline \multirow[b]{4}{*}{ Treatments } & \multirow{4}{*}{$\begin{array}{l}\text { Aphids no. } \\
\text { before } \\
\text { treatments }\end{array}$} & \multicolumn{12}{|c|}{ Aphids no. and their reduction percent after treatments } \\
\hline & & \multirow{2}{*}{\multicolumn{2}{|c|}{$\begin{array}{c}\text { Initial effect } \\
\text { 2-days }\end{array}$}} & \multicolumn{8}{|c|}{ Residual effect } & \multirow{2}{*}{\multicolumn{2}{|c|}{$\begin{array}{c}\text { Mean residual } \\
\text { effect }\end{array}$}} \\
\hline & & & & \multicolumn{2}{|c|}{ 3-days } & \multicolumn{2}{|c|}{ 5-days } & \multicolumn{2}{|c|}{ 7-days } & \multicolumn{2}{|c|}{ 9-days } & & \\
\hline & & No. & $\mathbf{R} \%$ & No. & $\mathbf{R} \%$ & No. & $\mathbf{R} \%$ & No. & $\mathbf{R} \%$ & No. & $\mathbf{R} \%$ & No. & $\mathbf{R} \%$ \\
\hline$A(100 \%)$ & 1575 & 1153 & 27.8 & 1050 & 32.8 & 898 & 46.8 & 532 & 67.8 & 642 & 62.6 & 780 & 52.5 \\
\hline$A+D(1$ & & 919 & 38.8 & 820 & 44.1 & 587 & 62.9 & 530 & 65.9 & 476 & 70.4 & 603 & 60.9 \\
\hline B (100\%) & 1 & 1026 & 33.5 & 921 & 38.9 & 363 & 77.7 & 472 & 70.4 & 602 & 63.6 & 589 & 62.7 \\
\hline$B+D$ & 1615 & 883 & 46.1 & 836 & 47.8 & 945 & 45.4 & 505 & 70.2 & 560 & 68.1 & 711 & 57.9 \\
\hline C (100\% & 1632 & 998 & 39.7 & 708 & 56.3 & 837 & 52.1 & 622 & 63.7 & 842 & 52.5 & 752 & 56.2 \\
\hline$C+D$ & 1810 & 1177 & 35.9 & 1067 & 40.6 & 713 & 63.2 & 652 & 65.7 & 785 & 60.1 & 804 & 57.4 \\
\hline $\mathrm{D}(1$ & & 493 & 71.8 & 286 & 83.3 & 446 & 75.9 & 578 & 68.1 & 752 & 59.9 & 515 & 71.8 \\
\hline Cont & & 1420 & - & 1389 & - & 1500 & - & 1470 & - & 1522 & - & - & - \\
\hline LSD $(P \leq 0.05)$ & 112 & 11 & 4.6 & 78 & 5.7 & 96 & 11.5 & 18 & 6.8 & 53 & 3.9 & 36 & 5.6 \\
\hline
\end{tabular}

$\mathrm{A}=$ Anthmis pseudocotula extract at $20 \%$ concentration; B = Fagonia arabica extract at $20 \%$ concentration; C = Salix alba extract at $20 \%$ concentration; $\mathrm{D}=$ Malathion at $57 \%$ concentration; $\mathrm{R} \%=$ Reduction percent of aphids.

Values followed the same letter are non-significant.

Table 2. Effect of some plant extracts and malathion on cations of the soil supporting apricot trees.

\begin{tabular}{|c|c|c|c|c|}
\hline Treatment & $\begin{array}{c}\mathrm{Ca}^{++} \\
(\mathrm{mg} / \mathrm{L})\end{array}$ & $\begin{array}{c}\mathrm{Mg}^{++} \\
(\mathrm{mg} / \mathrm{L})\end{array}$ & $\begin{array}{c}\mathrm{Na}^{++} \\
(\mathrm{mg} / \mathrm{L})\end{array}$ & $\begin{array}{c}\mathrm{K}^{+} \\
(\mathrm{mg} / \mathrm{L}) \\
\end{array}$ \\
\hline Anthmis pseudocotula extract at $20 \%$ concentration (100\%) & 197.9 & 65.7 & 190.9 & 21.9 \\
\hline Anthmis pseudocotula extract at $20 \%+$ Malathion at $57 \%(50 \%+50 \%)$ & 202.2 & 68.3 & 167.9 & 23.7 \\
\hline Fagonia arabica extract at $20 \%$ concentration (100\%) & 203.8 & 63.8 & 170.5 & 16.8 \\
\hline Fagonia arabica extract at $20 \%+$ Malathion at $57 \%(50 \%+50 \%)$ & 676.7 & 68.6 & 166.9 & 23.7 \\
\hline Salix alba extract at $20 \%$ concentration $(100 \%)$ & 623.9 & 165.9 & 280.8 & 44.6 \\
\hline Salix alba extract at $20 \%+$ Malathion at $57 \%(50 \%+50 \%)$ & 408.9 & 156.7 & 265.7 & 43.7 \\
\hline Malathion at $57 \%$ concentration $(100 \%)$ & 432.9 & 117.6 & 200.9 & 21.0 \\
\hline Control & 141.7 & 36.8 & 125.5 & 14.7 \\
\hline $\operatorname{LSD}(P \leq 0.05)$ & 54.8 & 35.8 & 24.8 & 2.6 \\
\hline
\end{tabular}

Table 3. Effect of some plant extracts and malathion on anions of the soil supporting apricot trees.

\begin{tabular}{|c|c|c|c|c|}
\hline Treatment & $\begin{array}{c}\mathrm{CO}_{3}^{--} \\
(\mathrm{mg} / \mathrm{L})\end{array}$ & $\begin{array}{l}\mathrm{HCO}_{3}^{-} \\
(\mathrm{mg} / \mathrm{L})\end{array}$ & $\begin{array}{l}\mathrm{SO}_{4}{ }^{2-} \\
(\mathrm{mg} / \mathrm{L})\end{array}$ & $\begin{array}{c}\mathrm{Cl}^{-} \\
(\mathrm{mg} / \mathrm{L})\end{array}$ \\
\hline Anthmis pseudocotula extract at $20 \%$ concentration (100\%) & - & 96.3 & 620.7 & 177.9 \\
\hline Anthmis pseudocotula extract at $20 \%+$ Malathion at $57 \%(50 \%+50 \%)$ & - & 87.9 & 666.8 & 168.9 \\
\hline Fagonia arabica extract at $20 \%$ concentration $(100 \%)$ & - & 80.9 & 630.8 & 198.9 \\
\hline Fagonia arabica extract at $20 \%+$ Malathion at $57 \%(50 \%+50 \%)$ & - & 85.9 & 634.9 & 211.0 \\
\hline Salix alba extract at $20 \%$ concentration $(100 \%)$ & - & 160.9 & 1380.7 & 330.9 \\
\hline Salix alba extract at $20 \%+$ Malathion at $57 \%(50 \%+50 \%)$ & - & 176.8 & 1324.9 & 333.8 \\
\hline Malathion at $57 \%$ concentration (100\%) & - & 80.7 & 640.8 & 220.8 \\
\hline Control & - & 89.6 & 570.9 & 122.5 \\
\hline $\operatorname{LSD}(\mathrm{P} \leq 0.05)$ & - & 19.2 & 21.5 & 31.0 \\
\hline
\end{tabular}

highest concentrations in the soil supporting treated apricot trees with $\mathrm{S}$. alba extract. Maximum values of anions: $\mathrm{HCO}_{3}{ }^{-}, \mathrm{SO}_{4}{ }^{2-}$ and $\mathrm{Cl}^{-}$concentrations in the soil were $160.52,1380$ and $330.31 \mathrm{mg} / \mathrm{L}$ for $S$. alba extracts, while minimum value was $80.26,620$ and $177.1 \mathrm{mg} / \mathrm{L}$ for F. arabica extracts. On the other hand, controls were 89.89, 570 and $122.07 \mathrm{mg} / \mathrm{L}$ for $\mathrm{HCO}_{3}{ }^{-}, \mathrm{SO}_{4}{ }^{2-}$ and $\mathrm{Cl}^{-}$ concentrations, respectively. 
Table 4. Effect of some plant extracts and malathion on photosynthetic pigments of apricot leaves trees.

\begin{tabular}{|c|c|c|c|c|c|c|c|c|c|}
\hline \multirow[b]{2}{*}{ Treatment } & \multicolumn{3}{|c|}{ Chlorophyll a } & \multicolumn{3}{|c|}{ Chlorophyll b } & \multicolumn{3}{|c|}{ Carotenoids } \\
\hline & 7-days & 14-days & Mean & 7-days & 14-days & Mean & 7-days & I4-days & Mean \\
\hline$A(100 \%)$ & 2.64 & 2.56 & 2.60 & 3.49 & 3.66 & 3.57 & 1.23 & 1.27 & 1.25 \\
\hline$A+D(1 v: 1 v)$ & 2.33 & 2.63 & 2.48 & 3.76 & 3.57 & 3.66 & 1.42 & 1.26 & 1.34 \\
\hline B (100\%) & 2.57 & 2.64 & 2.60 & 3.62 & 3.57 & 3.59 & 1.28 & 1.23 & 1.25 \\
\hline$B+D(1 v: 1 v)$ & 2.67 & 2.27 & 2.47 & 3.74 & 3.43 & 3.58 & 1.23 & 1.32 & 1.28 \\
\hline C (100\%) & 2.57 & 2.68 & 2.71 & 3.66 & 3.67 & 3.66 & 1.25 & 1.30 & 1.27 \\
\hline$C+D(1 v: 1 v)$ & 2.54 & 2.12 & 2.33 & 3.84 & 3.39 & 3.62 & 1.33 & 1.31 & 1.32 \\
\hline D (100\%) & 2.54 & 2.47 & 2.50 & 3.61 & 3.42 & 3.51 & 1.27 & 1.18 & 1.22 \\
\hline Control & 2.17 & 2.17 & 2.17 & 3.20 & 3.20 & 3.20 & 1.26 & 1.26 & 1.26 \\
\hline LSD $(P \leq 0.05)$ & 0.45 & 0.12 & 0.15 & 0.12 & 0.18 & 0.31 & 0.11 & 0.14 & 0.22 \\
\hline
\end{tabular}

$\mathrm{A}=$ Anthmis pseudocotula extract at $20 \%$ concentration; $\mathrm{B}=$ Fagonia arabica extract at $20 \%$ concentration; $\mathrm{C}=$ Salix alba extract at $20 \%$ concentration; $\mathrm{D}=$ Malathion at $57 \%$ concentration; $\mathrm{R} \%=$ Reduction percent of aphids.

Values followed the same letter are non-significant.

Table 5. Effect of some plant extracts and malathion on mean total carbohydrates and total proteins of apricot leaves trees.

\begin{tabular}{|c|c|c|}
\hline Treatment & $\begin{array}{c}\text { Total carbohydrates } \\
(\mathrm{mg} / \mathrm{g})\end{array}$ & $\begin{array}{c}\text { Total } \\
\text { proteins (\%) }\end{array}$ \\
\hline Anthmis pseudocotula extract at $20 \%$ concentration (100\%) & 29.9 & 12.5 \\
\hline Anthmis pseudocotula extract at $20 \%$ concentration + Malathion at $57 \%(50 \%+50 \%)$ & 27.9 & 11.9 \\
\hline Fagonia arabica extract at $20 \%$ concentration $(100 \%)$ & 27.3 & 13.9 \\
\hline Fagonia arabica extract at $20 \%$ concentration + Malathion at $57 \%(50 \%+50 \%)$ & 26.9 & 11.5 \\
\hline Salix alba extract at $20 \%$ concentration (100\%) & 29.9 & 28.3 \\
\hline Salix alba extract at $20 \%$ concentration + Malathion at $57 \%(50 \%+50 \%)$ & 28.8 & 29.8 \\
\hline Malathion at $57 \%$ concentration (100\%) & 25.3 & 29.3 \\
\hline Control & 27.1 & 26.0 \\
\hline LSD $(P \leq 0.05)$ & 1.8 & 1.7 \\
\hline
\end{tabular}

\section{Photosynthetic pigments}

We can infer from the combined data of the two weeks that the variations in the content of chlorophyll $a$ and $b$ and carotenoids in the leaves of apricot trees as affected by plant extracts and malathion treatments (Table 4). There was no significant increase in chlorophyll $a$ and $b$ content at 7 and 14 day after application of all treatments. It is evident that there were remarkable decreases in the content of carotenoids in the leaves of apricot trees treated with the same materials. There was high significance between all treatments compared with control in chlorophyll $\mathrm{a}, \mathrm{b}$ and carotenoids content. These results agree with El-Quesni and Radwan (1993) who found that the treatment with Topogard (terbuthylazine + terbutryn) on faba bean increased chlorophyll $a, b$ and chlorophyll $a+b$ content but decreased carotenoids in the leaves. Chlorophyll pigments, considered the most important chemical components that convert photoenergy to chemical energy, play an active role in photosynthesis and carotenoid pigments protect chlorophyll against pho- tooxidation and transfer of energy to chlorophyll.

\section{Total carbohydrates and proteins}

It is evident in Table 5 that there were significant increases in the mean total carbohydrates in the treated leaves of apricot trees with plant extracts; 29, 27.33 and $29 \%$ for $F$. arabica, A. pseudocofula and S. alba extract, respectively. The control has $27 \%$ carbohydrates but in case of Malathion the percentage decreased to $25.33 \%$. It was also clear that there was no significant increase in percentage of total protein in S. alba extract and Malathion treated palnts when compared to control, while there was significant decrease of total proteins in $F$. arabica and $A$. pseudocotula extracts treated plants (Table 5). In harmony with the above results, Woda (1994) reported that spraying potato plants with metribuzin reduced reducing sugars, non reducing sugars and starch in leaves of potato and influenced on protein metabolism. Carbohydrates and proteins are organic 
compounds used in tissue synthesis and organs synthesis.

\section{ACKNOWLEDGEMENT}

This study is part of the research activities of the Primary Center of Excellence of Biodiversity Research program, developed and funded by the Ministry of Higher Education, KSA. Thanks are expressed to anonymous referees for their constructive comments on the first draft of this paper.

\section{REFERENCES}

Bandara KA, Peries ID, Kumar V, Karunaratne V, Ranasinghe MA (1990). Insecticidal activity of Acorus calamus L. and Glycosmis mauritiana (Lam.) Tanaka against Aphis craccivora (Homoptera: Aphididae). Trop. Agric., 67(3): 223-228.

El-Quesni FEM, Radwan SM (1993). Effect of Topogard and micronutrients on growth, symbiotic nitrogen fixation and chemical composition of faba bean plants. Bulletin of Faculty of Agriculture, University of Cairo, 44(2): 315-332.
Ghamry KM (1986). The role of plant natural products on aphids infesting citrus trees of Sharkia Govemorate. M.Sc. Thesis, Fac. Agric. Zagazig University.

Hala MIM (2000). New approaches in the control of legumes aphids, Aphis craccivora (Koch) (Homoptera: Aphididae) M.Sc. Thesis, Institute of Environmental studies and Researches, Ain Shams University.

Handerson CF, Tilton EW (1955). Test with acaricides against the brown white mite, J. Econ. Entomol. 48: 157-161.

Jackson ML (1967). Soil Chemical Analysis. Hall of India Private, New Delhi, Indian, p. 248.

Metzner H, Rau H, Senger H (1965). Untersuchungen Zur Synchronisier barkeep ein Zelner pigment. Mango I Mutanten Von chlorella. Planta, 65: 186.

Venkaietan S, Bat-Ashbeamanian G, Jayari S, GopaJan M (1987). Studies on the efficacy of neem products against the aphid Aphis gossypii (Olov.) on cotton. Madrus. Agric. J. 74(45): 255-257.

Woda LM (1994). Biochemical changes in potato plants under the influence of carbofuron (furdan 50) and metrobuzin (Sencor). Instytutu Octrony Roslin 35(1- 2): 80-89. 